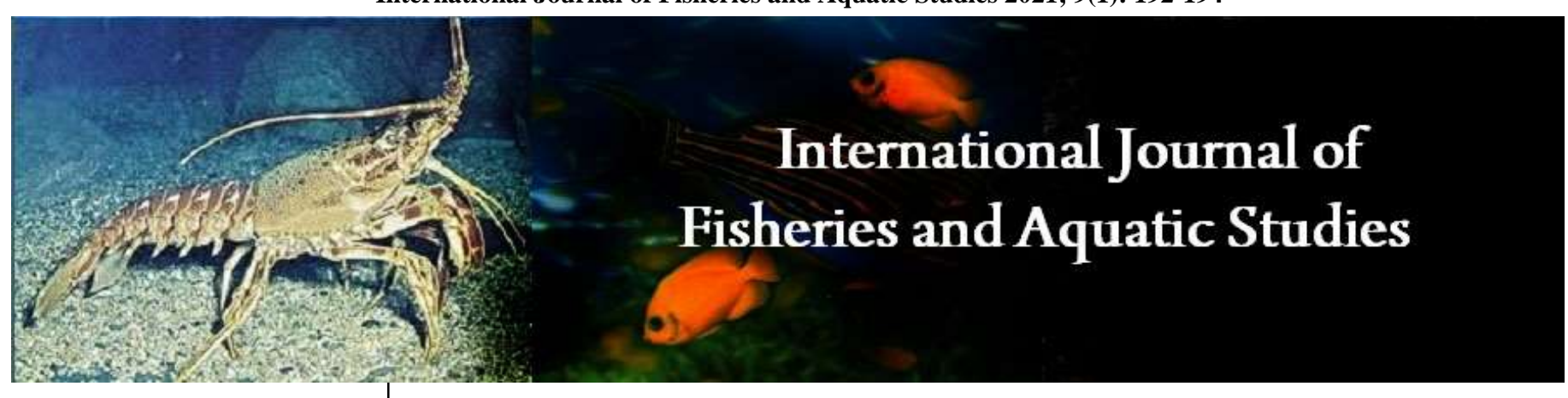

E-ISSN: 2347-5129

P-ISSN: 2394-0506

(ICV-Poland) Impact Value: 5.62

(GIF) Impact Factor: 0.549

IJFAS 2021; 9(1): 192-194

(C) 2021 IJFAS

www.fisheriesjournal.com

Received: $23-10-2020$

Accepted: 02-12-2020

Dian Yuni Pratiwi

Faculty of Fisheries and Marine

Science, Universitas

Padjadjaran, Indonesia

Fittrie Meyllianawaty Pratiwy Faculty of Fisheries and Marine

Science, Universitas

Padjadjaran, Indonesia

\section{Comparison of Ulva lactuca and Ulva clathrata as ingredients in Litopenaeus vannamei feeds}

\author{
Dian Yuni Pratiwi and Fittrie Meyllianawaty Pratiwy
}

DOI: https://doi.org/10.22271/fish.2021.v9.i1c.2401

\section{Abstract}

Ulva lactuca and Ulva clathrata are marine green algae belonging to genera Ulva. These algae have a lot of nutrient such as protein, carbohydrates, lipids, pigments and others. These nutrient can be used to improve the growth performance and health of Shrimps. Several studies have shown that $U$. lactuca and $U$. clathrata have antifungal, antibacterial, antiviral activities. One of popular shrimp among people of the world is Litopenaeus vannamei. So that, this review article aims to comparing the effect of $U$. lactuca and $U$. clathrata as ingredients in L. vannamei juvenile feeds. This review also summarizes a literature survey of the nutritional content and antimicrobial activity of $U$. lactuca and $U$. clathrata.

Keywords: Ulva lactuca, Ulva clathrata, Litopenaeus vannamei, growth, health

\section{Introduction}

Shrimps is one of popular seafood commodity among people of the world. The global trade of shrimp achieve 5.10 million tons in $2019^{[1]}$ and estimate at USD 28 billion per year ${ }^{[2]}$. Five major shrimps producing regions are China, India, Indonesia, Vietnam, and Thailand. The major shrimps consuming regions are United States of America, China, Europe, and Japan. Shrimps becoming popular worldwide because they contain a lot of nutrient such as mineral (calcium, zinc, iodine), vitamin D, vitamin B3, protein, and fatty acids ${ }^{[1]}$.

Among all shrimp's commodities, Litopenaeus vannamei is one of popular species to be consumed. High price, easy cultivated, and fast growing shrimps make this species popular to be cultivated. Price of L. vannamei in Indonesia is $\mathrm{Rp} 70.000 / \mathrm{kg}{ }^{[3]}$. Vannamei shrimp were introduction to Asian regions in 1978, and commercially into Mainland China and Taiwan Province of China in 1996, followed by most of the other coastal Asian countries in $2001{ }^{\text {[4] }}$. Although are easy to be cultivated but there are some challenge such as disease, quality and cheap feed stock availability ${ }^{[5]}$. So that, discovering new alternative feed ingredient with a lot of nutrient, low cost and antimicrobial activities should be done.

Ulva is one of algae genus with a lot of nutrient and antimicrobial activities. U. lactuca and $U$. clathrata are member of Ulva genus which can be used as feed ingredient because of their nutrition content. Some researchers have been conducted to learn about the effect of $U$. lactuca and $U$. clathrata to L. vannamei growth and health ${ }^{[6,7]}$. So that, this article aims to describe the nutritional content of $U$. lactuca and $U$. clathrata and their effects on growth and health of L. vannamei.

\section{Ulva lactuca and Ulva clathrata}

Ulva lactuca is bright green algae which can be black or white when dry. This algae live in marine water at high and low intertidal zone at depths of 75 feets or more. It lives free floating but can be found attached to rocks and shells by a holdfast. Size of $U$. lactuca is 6 inches-2 feet. It has flat, thin, broad, rounded or oval leaves. It can be used as bioindicator species because this algae can grows well in polluted water ${ }^{[8]}$. U. lactuca contains protein, lipid, carbohydrate, fibre ${ }^{[9]}$, secondary metabolite and others ${ }^{[10]}$.

Ulva clathrata is light green marine algae. It can be found in Indo-Pacific, Atlantic Ocean, and the Mediterranean at depths between 0-29 m. It can be found attached to solid substrates like rocks or floating. Its thalli is branched and hair like hollow filaments ${ }^{[11]}$, cylindrical or slightly flat. Ranges of size from $20-80 \mathrm{~mm}$ with a thread width of $1-3 \mathrm{~mm}^{[12]}$. High nutrition content made this algae can be used for used for human consumption, animal feed, and fertilizer ${ }^{[12]}$.
Dian Yuni Pratiwi

Faculty of Fisheries and Marine

Science, Universitas

Padjadjaran, Indonesia 


\section{Chemical Composition of Ulva lactuca and Ulva clathrata}

Ulva lactuca and Ulva clathrata contains various nutrients such as protein, carbohydrate, fat, vitamins, fibre, and minerals $\langle 9,13]$. The amino acids contained include aspartic acid, glutamic acid, serine, histidine, glycine, lysine, leucine, isoleucine, phenylalanine, valine, methionine, tyrosine, alanine, arginine, threonine ${ }^{[13,14]}$. They also have a lot of secondary metabolites namely phenolics, sapnonins, flavonoids, alkaloids, steroids ${ }^{[10,15]}$. Minerals in $U$. lactuca are sodium, calcium, potassium, phosphorus, iron ${ }^{[9]}$. Minerals in $U$. clathrata are calcium, iron, copper, zinc ${ }^{[13]}$. Pigments contained in $U$. lactuca include chlorophyll a, chlorophyll $\mathrm{b}$, neoxanthin, dinoxanthin, anteraxanthin [16]. While the pigments in $U$. clathrata include xanthophylls, carotenoids ${ }^{[13]}$. The chemical composition of U. lactuca and $U$. Clathrata can be seen in the table below.

Table 1: Proximate Analysis of U. lactuca and U. clathrata

\begin{tabular}{|c|c|c|}
\hline Composition & U. lactuca & U. clathrata \\
\hline Crude Protein $(\% \mathrm{dw})$ & $19.34 \pm 0.2$ & $20.1 \pm 0.1$ \\
\hline Crude fat $(\% \mathrm{dw})$ & $3.46 \pm 0.1$ & $2.2 \pm 0.1$ \\
\hline Ash (\% dw) & $44.1 \pm 0.1$ & $27.5 \pm 0.2$ \\
\hline Dietary fibre & $25.81 \pm 0.2$ & $40.6 \pm 3.0$ \\
\hline reference & {$[17]$} & {$[13]$} \\
\hline
\end{tabular}

Table 2: Amino Acids Content of U. lactuca and U. clathrata (g/100 g protein)

\begin{tabular}{|c|c|c|}
\hline Amino acid & U. lactuca & U. clathrata \\
\hline Aspartic acid & $12.3 \pm 0.9$ & $11.14 \pm 0.08$ \\
\hline Threonine & $4.7 \pm 0.0$ & $4.59 \pm 0.10$ \\
\hline Serine & $5.9 \pm 0.0$ & $4.69 \pm 0.27$ \\
\hline Glutamic acid & $9.0 \pm 0.5$ & $12.8 \pm 0.32$ \\
\hline Proline & $5.3 \pm 0.6$ & $2.85 \pm 0.03$ \\
\hline Glycine & $10.7 \pm 0.6$ & $5.8 \pm 0.04$ \\
\hline Alanine & $14.2 \pm 0.4$ & $8.64 \pm 0.05$ \\
\hline valine & $6.2 \pm 0.0$ & $5.55 \pm 0.10$ \\
\hline Methionine & $1.6 \pm 0.1$ & $1.56 \pm 0.01$ \\
\hline Tyrosine & $2.1 \pm 0.1$ & $1.79 \pm 0.06$ \\
\hline cysteine & $0.4 \pm 0.4$ & $1.99 \pm 0.03$ \\
\hline Isoleucine & $3.7 \pm 0.0$ & $3.26 \pm 0.08$ \\
\hline Leucine & $6.7 \pm 0.1$ & $4.99 \pm 0.04$ \\
\hline Phenylalanine & $4.0 \pm 0.0$ & $4.41 \pm 0.04$ \\
\hline lysine & $4.2 \pm 0.1$ & $3.61 \pm 0.10$ \\
\hline Histidine & $1.8 \pm 0.1$ & $0.98 \pm 0.01$ \\
\hline Arginine & $3.6 \pm 0.3$ & $6.21 \pm 0.10$ \\
\hline Reference & {$[18]$} & {$[13]$} \\
\hline \multicolumn{2}{|c}{} \\
\hline
\end{tabular}

Table 3: Fatty acid content of U. lactuca and U. clathrata (\%)

\begin{tabular}{|c|c|c|}
\hline Fatty acid groups & U. lactuca & U. clathrata \\
\hline SFA & 47.90 & $43.7 \pm 1.1$ \\
\hline MUFA & 40.63 & 25.1 \\
\hline PUFA & 12.86 & 31.2 \\
\hline HUFA & 5.5 & 10.4 \\
\hline Reference & {$[19]$} & {$[20]$} \\
\hline
\end{tabular}

Table 4: Minerals content of $U$. lactuca and $U$. clathrata $(\mathrm{mg} / \mathrm{kg}$ $\mathrm{dw})$

\begin{tabular}{|c|c|c|}
\hline Mineral & U. lactuca & U. clathrata \\
\hline Iron & 228.6 & 4172 \\
\hline Copper & 5.7 & 13.80 \\
\hline Calcium & 1892 & 18800 \\
\hline Zinc & 42.16 & 16.66 \\
\hline cadmium & 0.27 & 1.32 \\
\hline chromium & $0 . .87$ & 0.80 \\
\hline nickel & 5.51 & 5.72 \\
\hline Reference & {$[21]$} & {$[13]$} \\
\hline
\end{tabular}

4. Ulva lactuca and Ulva clathrata As Antimicrobial Agent Secondary metabolites content of U. lactuca and U. clathrata have antimicrobial activities. Organic extract of $U$. lactuca grown in natural sea water and artificial sea water show antimicrobial activities against Bacillus cereus, Bacillus substilis, Staphyloccus aureus, Micrococcus luteus, Serralia marcescens, Klebsiella pneumoniae ${ }^{[22]}$. 3-O- $\beta-\mathrm{D}$ glucopyranosyl-stigmasta-5, 25-dien in $U$. lactuca has topical antiinflammatory activity ${ }^{[23]}$. $U$. clathrata also show antimicrobial activities against Klebsiella sp, S. aureus, and Pseudomonas aeruginosa ${ }^{[24]}$. Ulvan extracted from $U$. clathrata show antiviral effect to paramyxovirus ${ }^{[25]}$.

\section{Effect of Ulva lactuca and Ulva clathrata as ingredients of Litopenaeus vannamei feed}

$U$. lactuca and $U$. clathrata have been shown to have a positive effect to L. vannamei. Provision $U$. clathrata in juvenile L.vannamei diet for 28 days showed that this algae had a positive effect on growth performance ${ }^{[7]}$. This algae also enhances the reproductive performance of L. vannamei ${ }^{[26]}$. Provision $U$. lactuca in juvenile L.vannamei diet for 28 days also showed that this alga had a positive effect on growth performance ${ }^{[6]}$. Besides that, polysaccharide extract from $U$. lactuca can enhance the phagocytic activity of the $L$. vannamei ${ }^{[27]}$. The comparison of $U$. lactuca and $U$. clathrata on growth performance of $L$. vannamei can be seen on table 5 .

Table 5: The comparison of $U$. lactuca and $U$. clathrata on growth performance of $L$. vannamei can be seen

\begin{tabular}{|c|c|c|}
\hline Parameter & U. lactuca & U. clathrata \\
\hline Initial weight $(\mathrm{g})$ & 0.3 & 1.59 \\
\hline Final Weight $(\mathrm{g})$ & 2.15 & 4.79 \\
\hline Weight gain (\%) & 613 & 203 \\
\hline FCR & 1.19 & 1.78 \\
\hline FC & 2.22 & 5.71 \\
\hline Survival Rate (\%) & 90 & 95 \\
\hline Reference & {$[6]$} & {$[7]$} \\
\hline
\end{tabular}

\section{Conclusion}

In conclusion, $U$. lactuca and $U$. clathrata contains various nutrients such as protein, amino acids, carbohydrates, lipids, pigments and others. U. lactuca and U. clathrata may produce compounds that have antiviral and antibacterial activity for $L$. vannamei. So that, $U$. lactuca and $U$. clathrata can be used as alternative feed ingredients.

\section{References}

1. Quick dissolving tablets. https://www.imarcgroup.com/prefeasibility-reportshrimp-processing-plant. 2020.

2. Fao. Globefish Highlights January 2020 issue, with Jan. Sep. 2019 Statistics - A quarterly update on world seafood markets. Globefish Highlights no. 1-2020. Rome 2020. https://doi.org/10.4060/ca7968en

3. Budiardi T, Muzaki A, Utomo NBP. White Shrimp (Litopenaeus vannamei) Production on Different Rearing Densities in Biocrete Pond. Jurnal Akuakultur Indonesia 2005;4(2):109-113.

4. Briggs M, Funge-Smith S, Subasinghe R, Phillips M. Introductions and movement of Penaeus vannamei and Penaeus stylirostris in Asia and the Pacific. RAP Publications 2004.

5. Anderson JL, Valderrama D, Jory DE. Goal. Global Shrimps Production Review. Quick dissolving tablets 
2019.

https://www.aquaculturealliance.org/advocate/goal-2019global-shrimp-production-review/

6. Elizondo-Gonzales R, Quiroz-Guzmin E, EscobedoFregoso C, Magallon-Servin P, Pena-Rodriguez A. Use of seaweed Ulva lactuca for water bioremediation and as feed additive for white shrimp Litopenaeus vannamei. Peer J 2018.

7. Cruz-Suarez LE, Tapia-Salazar M, Nieto-Lopez MG, Guajardo-Barbosa C, Ricque-Marie. Comparison of Ulva clathrata and the kelps Macrocystis pyrifera and Ascophyllum nodosum as ingredients in shrimp feeds. Aquaculture nutrition 2009;15:421-430.

8. Quick dissolving tablets (http://www.edc.uri.edu/restoration/html/gallery/plants/se a.htm) 2020.

9. Rasyid A. Evaluation of Nutritional Composition of The Dried Seaweed Ulva lactuca from Pameungpeuk Waters, Indonesia. Tropical Life Sciences Research 2017;28(2):119-125.

10. Shankhadarwar SD. Phytochemical screening of marine algae Ulva lacuta (Linn.) and Enteromorpha intestinalis (Linn.). Journal of Chemical and Pharmaceutical Research 2015;7(12):419-423.

11. Quick dissolvin https://www sealifebase.st 2020.

12. Quick dissolving tablets http://www.flora.sa.gov.au/efsa/algae revealed/pdf/Enter omorpha clathrata.pdf 2020.

13. Peña-Rodríguez A, Mawhinney TP, Ricque-Marie D, Cruz-Suárez LE. Chemical composition of cultivated seaweed Ulva clathrata (Roth) C. Agardh. Food Chemistry 2011;129:491-498.

14. Yu-Qing T, Mahmood K, Shehzadi R, Ashraf MF. Ulva Lactuca and Its Polysaccharides: Food and Biomedical Aspects. Journal of Biology, Agriculture and Healthcare 2016;6(1):491-498.

15. Cotas J, Leandro A, Monteiro P, Pacheco D, Figueirinha A, Gonçalves AMM et al. Seaweed Phenolics: From Extraction to Applications. Marine drugs 2020;18(8):384.

16. De Costa JF, Merdekawati W, Otua FR. Analisis proksimat, aktivitas antioksidan, dan komposisi pigmen Ulva lactuca L. dari perairan pantai kukup. Jurnal Teknologi Pangan dan Gizi 2018;17(1):1-17.

17. El Din SMM. Temporal variation in chemical composition of Ulva lactuca and Corallina mediterranea. International Journal of Environmental Science and Technology 2019;16:5783-5796.

18. Shuuluka D, Bolton JJ, Anderson RJ. Protein content, amino acid composition and nitrogen-to-protein conversion factors of Ulva rigida and Ulva capensis from natural populations and Ulva lactuca from an aquaculture system, in South Africa. Journal of Applied Phycology 2013;25:677-685.

19. Caf F, Yilmaz O, Durucan F, Özdemir NS. Biochemical components of three marine macroalgae (Padina pavonica, Ulva lactuca and Taonia atomaria) from the Levantine Sea coast of antalya, Turkey. Journal of Biodiversity and Environmental Sciences 2015;6(4):401411.

20. Corral-Rosales C, Ricque-Marie D, Cruz-Suárez LE, Arjona O, Palacios E. Fatty acids, sterols, phenolic compounds, and carotenoid changes in response to dietary inclusion of Ulva clathrata in shrimp Litopenaeus vannamei broodstock. Journal of Applied Phycology 2019;31:4009-4020.

21. El Din SMM, Hassan SM. The Promotive Effect of Different Concentrations of Marine Algae on Spinach Plants (Spinacia oleracea L.) Egyptian Journal of Horticulture 2016;43(1):109-122.

22. El-Baky HA, El-Baz FK, Baroty GSE. Com 434 Evaluation of Marine Alga Ulva lactuca as A Source of Natural Preservative Ingredient. American-Eurasian Journal Agricultural \& Environmental Science 2008;3(3):434-444.

23. Awad NE. Biologically active steroid from the green alga Ulva lactuca. Phytotheraphy Research 2000;14(8):641643.

24. Rebecca J, Dhanalakshmi V, Sharmila S, Merina Paul Das. In vitro antimicrobial activity of Gracilaria sp and Enteromorpha sp. Research Journal of Pharmaceutical, Biological and Chemical Sciences 2013;4(1):693-697.

25. Aguilar-Briseño JA, Cruz-Suarez LE, Sassi J-F, RicqueMarie D, Zapata-Benavides P, Mendoza-Gamboa E et al. Sulphated Polysaccharides from Ulva clathrata and Cladosiphon okamuranus Seaweeds both Inhibit Viral Attachment/Entry and Cell-Cell Fusion, in NDV Infection. Marine Drugs 2015;13(2):697-712.

26. Corral-Rosales DC, Palacios E, Ricque-Marie D, CruzSuárez LE. Enhancement of reproductive performance in shrimp Litopenaeus vannamei (Boone, 1931) by supplementation of Ulva clathrata meal in maturation diet in two commercial hatcheries. Aquaculture Research 2018;49:1053-1059.

27. Suleman Andayani S, Yuniarti A. The Effect of Ulva lactuta Polysaccharide Extract on Total Haemocyte Count and Phagocytic Activity of L. vannamei. Research Journal of Life Science 2018;5(3):156-162. 